\title{
Ética e hospitalidade: o motivo do monstro em O filho da mãe, de Bernardo Carvalho
}

Paulo César S. Oliveira ${ }^{1}$

Quando os cantores são assassinados e as canções arrastadas aos museus e presas ao passado, a geração atual torna-se ainda mais desolada, mais abandonada e mais perdida, mais deserdada, no sentido verdadeiro da palavra.

Roman Jakobson

No romance Grande sertão: veredas, de Guimarães Rosa, publicado em 1956, Riobaldo, narrador e personagem central da obra, logo no início de sua fala, esclarece a seu interlocutor, um sujeito letrado da cidade, que os tiros ouvidos não se deviam à briga de homem, mas à execução de um animal nascido com uma malformação: "um bezerro branco, erroso, os olhos de nem ser - se viu -, e com máscara de cachorro". O ser abjeto, visto pela população local como um híbrido monstruoso, fora eliminado com as armas emprestadas por Riobaldo, que, entretanto, autoproclamase livre de superstições e, por isso, acima das crendices do povo: "Mesmo que, por defeito como nasceu, arrebitado de beiços, esse figurava rindo feito pessoa. Cara de gente, cara de cão: determinaram - era o demo. Povo prascóvio. Mataram" (Rosa, 2006, p. 7).

A morte do híbrido monstruoso, do indesejado das gentes cuja anomalia era prenúncio de mau agouro e por isso deveria ser eliminado, é a princípio tratada por Riobaldo como um mero caso de ignorância do povo "prascóvio" que, na falta de uma reflexão racional, credita o fenômeno na conta da manifestação demoníaca, representada pelo bezerro com cara de gente e de cão. No decorrer do relato do ex-jagunço, veremos que sua alegada racionalidade também é duvidosa, e mais, saberemos que a deformação do bezerro erroso é mais importante para Riobaldo do que ele quer fazer crer seu interlocutor, ao acusar a ignorância de seus vizinhos. O leitor atento perceberá que a trajetória de vida de Riobaldo foi toda ela pontuada por uma falha trágica, tangenciada na dupla articulação entre o sublime e o abjeto, ou ainda,

${ }^{1}$ Doutor em letras e professor da Universidade do Estado do Rio de Janeiro (Uerj), Rio de Janeiro, RJ, Brasil. E-mail: paulo.centrorio@uol.com.br 
entre o sagrado e o demoníaco que digladiavam em seu espírito. Riobaldo, homem duro e valente, forjado nos códigos de honra e moral da jagunçagem, crê-se apaixonado pelo amigo Diadorim, obviamente um amor impossível de se realizar diante das convenções daquele mundo preestabelecido em que ele mergulhara. Daí que o sentimento amoroso pelo parceiro de jagunçagem, que na verdade, sabemos, era a donzela Maria Deodorina - o leva ao abismo do desespero quando, ao final de suas aventuras e desventuras, Riobaldo descobre o engano em que fora enredado - supostamente, por força de um pacto travado com o diabo. O diabo não é assunto de rasa importância para Riobaldo, embora ele tente nos convencer do contrário. Não sem razão, nas primeiras páginas de seu imenso relato, a reflexão sobre a figura do diabo toma conta da narrativa e nada menos do que nove nomes para a entidade são por ele relacionados: "Rincha-mãe, Sangue d'Outro, o Muitos-Beiços, o Rasgaem-Baixo, Faca-Fria, o Fancho-Bode, um Treciziano, o Azinhavre... o Hermógenes... Deles, punhadão" (Rosa, 2006, p. 10). Acresce-se que, no desfecho de sua longa narrativa, Riobaldo novamente confere proeminência à figura do diabo, o que nos leva a acreditar que ela é, na verdade, uma presença crucial à matéria vertente de sua fabulação.

Quase 20 anos mais tarde, em 1975, o romance Lavoura arcaica, de Raduan Nassar, retomará a imagem-força da monstruosidade alegorizada por Guimarães Rosa na figura do bezerro "erroso" e com riso de gente, dessa vez, não por intermédio de um animal, mas por uma das personagens centrais da obra, André, que, juntamente com sua irmã Ana, formam o par problemático de que a narrativa trata. Dessa vez, a questão da monstruosidade se manifesta através do amor incestuoso, e consumado, entre André e sua irmã. Também André se verá como parte de uma insólita "confraria de enjeitados, dos proibidos, dos recusados pelo afeto, dos sem-sossego, dos intranquilos, dos inquietos, dos que se contorcem, dos aleijões com cara de assassino que descendem de Caim". André é um sujeito que traz na testa um sinal, uma "longínqua cicatriz de cinza dos marcados pela santa inveja, dos sedentos de igualdade e de justiça, dos que cedo ou tarde acabam se ajoelhando no altar escuro do Maligno" (Nassar, 1989, p. 139).

Como podemos perceber, o tema da monstruosidade, que em Riobaldo pontua o processo de queda derivado da ruminação de uma culpa pressuposta, por conta do amor pelo companheiro Diadorim, na história de André será configurado no motivo do monstro, na figura de 
um sujeito que transgride a norma civilizadora expressa pela interdição do incesto. Em Lavoura arcaica, o problema da transgressão será tratado com múltiplas gradações, estendendo-se da crítica cultural à reflexão social, rondando o debate religioso, o espaço psicanalítico e o domínio do antropológico, inclusive ganhando tons políticos. Com esse romance, Raduan Nassar amplia as questões que Guimarães Rosa esboçara e desenvolvera no Grande sertão: veredas, nelas inserindo a possibilidade de transgressão como um dos componentes críticos a serem considerados quando se trata de confrontar as estruturas dogmáticas do mundo judaico-cristão ali representado com o mundo socialmente elaborado na cena da enunciação literária.

No discurso de André, nota-se que a apropriação do mito de Dioniso - com o qual o personagem-narrador se identifica - irá revelar as formas com que o recurso de chamamento à arkhé é um dado relevante para que o leitor compreenda a construção romanesca de Nassar: Dioniso era o filho bastardo nascido da união entre um deus (Zeus) e uma mortal. Para ter sua vida preservada, ganha do pai divino o disfarce de um bode, para que pudesse escapar da fúria de Hera, esposa de Zeus. Dioniso crescerá e será reconhecido, entre outras facetas, como o cultor da parreira, sendo por conta dos frutos dessa planta que ele descobrirá o vinho e seus poderes. As habilidades de Dioniso estão ligadas a forças vitais, que por vezes levam à desmedida, e sua ação no mundo o tornará patrocinador das performances dramáticas, alçado que foi à condição de protetor do teatro. Dioniso é também uma entidade virulenta, cuja ira se mostra, principalmente, quando é provocado ou negado em seus direitos, o que o faz gerar caos e loucura na vida dos que se recusam a reconhecê-lo em sua plena divindade. Ele é também uma espécie de deus estrangeiro ou mesmo uma das formas do abjeto: Dioniso pode ser lido como o deus não reconhecido, que se afirma na invocação das forças da demência e na promoção das bacanais, desestabilizando assim a ordem vigente, que o nega, e apontando para um novo estatuto no âmbito das instituições por ele afrontadas.

A referência constante ao panteísmo grego e às formas ancestrais do paganismo cristão são aspectos de grande impacto e importância na economia narrativa de Lavoura arcaica, e não sem motivos a imagem que abre o romance insere o leitor em uma atmosfera de embriaguez dos sentidos, de transgressão. Estamos falando da cena em que Pedro, o irmão primogênito e, consequentemente, o primeiro 
da nova linhagem, encontra André abrigado em uma pensão interiorana, após ter abandonado a família:

Os olhos no teto, a nudez do quarto; róseo, azul ou violáceo, o quarto é inviolável; o quarto é individual, é um mundo, quarto catedral, onde, nos intervalos da angústia, se colhe, de um áspero caule, na palma da mão, a rosa branca do desespero, pois entre os objetos que o quarto consagra estão os objetos do corpo; eu estava deitado no assoalho do meu quarto, numa velha pensão interiorana, quando meu irmão chegou para me levar de volta (Nassar, 1989, p. 9-10).

Antes da chegada do irmão, a narrativa acompanha André na manipulação de seu corpo, no ato solitário e na exploração de si, no "quarto-catedral" da velha pensão, que exalava vinho. A chegada do irmão interrompe, como um "sopro escuro no porão da memória", a autodescoberta e o mergulho em si, e as batidas na porta despertam o personagem para a realidade do mundo circundante e do tempo presente. As primeiras palavras de Pedro são, sugestivamente, imperativas: "abotoe a camisa, André" (Nassar, 1987, p. 12).

Percebemos haver ali um sistema de relações, já inaugurado por Guimarães Rosa no Grande sertão: veredas, e que será sensivelmente ampliado por Raduan Nassar, em Lavoura arcaica. Se por um lado Riobaldo é a representação do sujeito vítima de um engano trágico, por conta, tanto de sua incapacidade de tomar uma decisão com vistas a consumar o amor por Diadorim, quanto por não conseguir decifrar os signos em torno do mistério de seu/sua amado/amada, Rosa, entretanto, por meio dessa indecisão e desse fracasso, questiona intensamente a forma como as estruturas sociais, culturais, religiosas, políticas do mundo traçam limites e determinam os alcances de uma ética de si e da atitude perante o outro. Trata-se de viver, perigosamente, a busca de uma liberdade qualquer em um mundo de impedimentos e leis ancestrais. Essa questão avança na obra em questão de Nassar, por conta da efetiva consumação do desejo incestuoso entre André e sua irmã, Ana, o que não impede que a brutalidade da ordem recaia sobre ela, assassinada pelo pai, no momento em que Pedro lhe revela o terrível segredo familiar. Em ambos os casos, o de Riobaldo e o de André, as vítimas sacrificiais (Diadorim e Ana) representam a força do poder e da ordem ancestral, em que determinados arquétipos que preservam o equilíbrio do projeto civilizador, seja pela cultura ou pela 
violência, deverão prevalecer sobre as forças da mudança, supostamente em nome do bem comum social, mesmo que para isso a violência ritual tenha que ser reencenada sob a forma da barbárie. Nesse sentido, o alcance político das palavras de André nos faz perguntar sobre o sentido da ética como questão fundamental à fabulação nas duas obras. Rosa e Nassar ficcionalizam, portanto, a trajetória de sujeitos degradados em um mundo degradado, que no romance encontram, possivelmente, a mais completa tradução para seus dramas.

Este preâmbulo, com foco nas duas obras, Grande sertão: veredas e Lavoura arcaica, é essencial porque prepara o terreno histórico para possamos pensar um determinado caminho percorrido na literatura brasileira em que, ao contrário da visão historiográfica, uma nova série literária possa ser pensada como eficaz à compreensão das linhas de força que configuram nossa história literária. Nesse sentido, a inclusão nesta série de uma terceira narrativa, bem mais recente, a de $O$ filho da mãe, de Bernardo Carvalho (2009), pode confirmar a validade desse percurso, que vê na problematização do motivo do monstro uma chave de leitura, uma das passagens nos textos que torna possível compreender um certo percurso, seja pela análise diacrônica seja pelo aspecto sincrônico, de algumas obras que conferem singularidade à questão da monstruosidade na literatura brasileira.

Por meio da leitura de $O$ filho da mãe, enfatizaremos a tese de que o problema da ética, que provoca a questão das reações entre um eu e um outro, será novamente trazido ao centro do debate, desta feita situando o debate em nosso mundo contemporâneo o qual, por meio da alegoria da monstruosidade, será relido e reapresentado através dos embates entre as formas históricas que depreendemos do discurso romanesco, através das línguas estilizadas no romance carvaliano, com as estruturas sociais que essas línguas revelam através da leitura crítica, por meio de um processo dialógico que iremos exemplificar, inicialmente, por meio da seguinte passagem:

Quando eu era pequeno, viajando pelas montanhas com o meu pai, para conhecer a terra dos seus antepassados, passamos por uma casa onde havia nascido um animal que era dois sem ser nenhum. Uma égua dera à luz um potro no qual estavam misturados dois embriões. A isso chamam quimera, como depois eu ia aprender na faculdade. Era um animal estranho, parecia um potro, mas era outra coisa, dois fundidos num só, indistintos. Não conseguia ficar em pé. As quimeras são raras e os pastores nas 
montanhas as veem como portadoras de mau agouro, porque põem a reprodução num impasse, fazem da reprodução uma monstruosidade. Por isso, quando esses animais não morrem ao nascer, os próprios camponeses se encarregam de lhes dar um fim. Nas montanhas, todo homem tem um kunak, um amigo estrangeiro que o salvará da morte e que ele também tem a obrigação de salvar. Nenhum homem será completo enquanto não encontrar o seu kunak. Só então poderá seguir o próprio caminho em paz, sabendo que existe no mundo alguém, como ele, com quem ele pode contar na vida e na morte. As quimeras morrem para que sobreviva o pacto dos que não podem contar nem com Deus nem com os anjos (Carvalho, 2009, p. 161).

Como se vê nesse momento da narrativa, a pessoa que fala como se fosse um eu-narrador - já que em $O$ filho da mãe a quase totalidade do discurso é controlada por um narrador heterodiegético - informa acerca de uma estrutura mundo-ficcional em que aquilo que é dito por esse sujeito representa as verdades de todo um corpo social determinado, cujas ideias, fatos, organizações e ideologias se materializam por meio desta voz e por todas as outras vozes que o autor incorpora a seu discurso. Segundo Mikhail Bakhtin (1988, p. 134), “o romancista não conhece apenas uma linguagem única, ingênua (ou convencionalmente) incontestável e peremptória. A linguagem é dada ao romancista estratificada e dividida em linguagens diversas". Dessa forma, Bakhtin advoga o pluringuismo disseminado no romance como a característica fundamental do gênero, em que "o homem que fala e sua palavra são objeto tanto de representação verbal como literária"; "o sujeito que fala no romance é um homem essencialmente social, historicamente concreto e definido e seu discurso é uma linguagem social (ainda que em embrião), e não um 'dialeto individual",; "o sujeito que fala no romance é sempre, em certo grau, um ideólogo, e suas palavras são sempre um ideologema" (Bakhtin, 1988, p. 135).

Podemos considerar que a voz dessa pessoa que fala na passagem supracitada de $O$ filho da mãe só é possível porque uma instância superior - a do sujeito da enunciação que controla o discurso no romance, uma voz heterodiegética que concede aos personagens o direito de expressar a visão de mundo, sua e de sua classe - revela na narrativa o discurso do autor (Bakhtin, 1988, p. 137), imbricado de forma indissociável no discurso do narrador. 
Antes de avançarmos na análise do romance de Carvalho e de tratarmos do modo como essas vozes e esse processo dialógico de leitura são verificados na obra, propomos uma breve interrupção, necessária para que possamos retomar a ideia de uma série literária, aqui representada pela frase de Arthur Rimbaud, que data de 1871 e foi retirada de sua carta a Paul Démeny: "EU é um outro". Esta famosa frase nos estimula a pensar no que seria a literatura nova que Rimbaud anunciava como sendo moderna, como um "salmo da atualidade: Canto de guerra parisiense" (Rimbaud, 2015, p. 1). Para Rimbaud (2015, p. 1), “o primeiro estudo do homem que se quer poeta é o conhecimento de si mesmo, inteiro; ele busca sua alma, ele a observa, tenta, aprende (instrui)". Rimbaud está tentando definir ou pensar a literatura nova ao mesmo tempo em que procura apontar, na curvatura da modernidade, o advento de uma espécie de "alma monstruosa" 2 (Rimbaud, 2015, p. 1) que só o poeta vidente pode enxergar na obscuridade de um tempo em que se deve promover o "desregramento de todos os sentidos" (Rimbaud, 2015, p. 2). Essa atitude demolidora, uma das matrizes da consciência moderna revolucionária, expressava a possibilidade de construção/reconstrução do homem novo, de uma inteligência nova que pudesse lidar eficientemente com as pulsões de morte, subordinando-as ao poder vital da ação humana sobre si e sobre a realidade. Ao contrário da tese de Rimbaud, a promessa de uma energia vital e propulsora da modernidade, o século XX nos legou duas grandes guerras e a barbárie máxima do Holocausto. A produção de terror e morte abafou as vozes de liberdade e fez soar, em seu lugar, os cantos de catástrofe.

A constituição desses "eus" vitais se deu em meio aos cataclismos de um século XX entrecortado por avanços notáveis no campo da ciência, da arte e do pensamento, que, entretanto, foram ofuscados pela produção sistemática de barbárie, cujos efeitos iriam revelar, desde a banalização do mal e a constituição de tecnologias de terror até a diáspora forçada de sujeitos em busca de um lugar no mundo da promessa, cujo exemplo maior é hoje o drama dos refugiados, em diversas partes do globo. A construção de uma sociedade igualitária, com melhores oportunidades para o conjunto da população esbarra

\footnotetext{
${ }^{2}$ Essa alma monstruosa não é a mesma produzida artificialmente pelos comprachicos, citados por Rimbaud, que eram espécie de bandidos, nômades, geralmente, estrangeiros, que no século XVII deformavam crianças, transformando-as em aberrações para freak shows, e que foram retratados por Victor Hugo no romance $O$ homem que ri (1869).
} 
em estruturas de impedimentos geradas por uma modernidade que em seu estatuto se propunha dinâmica, plural e progressista, mas que, na maior parte das regiões do planeta, mostrou-se claudicante, excludente, atrasada.

Para melhor pensarmos essas questões e o tratamento ficcional a elas dado é que propomos a leitura do romance $O$ filho da mãe, de Bernardo Carvalho. Com ele, discutiremos os limites e alcances do texto literário no trato com o mundo da vida, através das ideias de mobilidade, pertencimento e diferença. Queremos mostrar como esse mundo de clausura, apagamento e segregação, cujas relações são marcadas pelas tensões entre o eu e o outro, é fundamental para a construção ético-poética de $O$ filho da mãe e igualmente importante para percebermos a inserção desta obra na série literária que neste artigo se iniciou com Grande sertão: veredas e Lavoura arcaica, mas cuja origem (seria possível uma origem?) se perde nas brumas do passo, como no exemplo de Rimbaud.

Primeiramente, quando observamos o conceito de obra aberta, verificado no tratamento dado às múltiplas possibilidades de abordagem crítica do texto, entendemos de imediato que a série literária articula-se com o mundo da vida (Lebenswelt) ${ }^{3}$ e provoca uma força de saberes que nos leva a relacionar o diálogo crítico inserido no texto artístico com os fenômenos do mundo que ele representa. Os atos de predizer e descrever o mundo da vida que a obra literária retoma, ao recriá-lo por meio da ficcionalização, revelam, por um lado, a estrutura geral do discurso narrativo e, por outro, $\mathrm{o}$ caráter descritivo desse discurso. Ao comentar a obra de Bakhtin, Michael Holquist (apud Bakhtin, 2014, p. xxvii) aponta que a estrutura sincrética dos romances é ainda pouco explorada, muito embora os avanços do teórico russo nesse campo tenham sido notáveis, especialmente quando mostra que as comparações entre história e narrativa romanesca presumiam sempre uma completude de inventário presente em ambos os discursos. No entanto, Holquist lembra que o gênero romanesco, definido por Bakhtin como um híbrido de linguagens, forja a história, porém deixando claro que o caráter original do romance encontra-se naquilo que é enunciado por meio do ato da enunciação, em que se revela a dupla

\footnotetext{
${ }^{3}$ Não iremos aprofundar neste momento a questão filosófica do mundo da vida (Lebenswelt), conforme pensaram inicialmente Edmund Husserl e, mais recentemente, Jürgen Habermas. O termo será utilizado aqui, provisoriamente, no âmbito das relações entre experiência e vivência percebidas na estrutura romanesca de $O$ filho da mãe, o que implica, em trabalho futuro, reconduzir as questões inicialmente pensadas por Husserl a uma reflexão conceitual-filosófica mais bem apurada.
} 
articulação autor/narrador, dramatizada na estrutura do discurso romanesco por meio de um gap, um intervalo ou espaço entre o que é dito e a forma de dizer (Holquist apud Bakhtin, 2014, p. xxix).

Em $O$ filho da mãe, notamos que a organização narrativa estimula os leitores a pensarem a aliança na qual o jogo com os signos se combina com a conjuntura descritiva que rasura, revela e questiona as configurações ideológicas, políticas e históricas do discurso. Desse modo, as relações entre ficção histórica avultam por meio daquilo que Richard Johnson (2004, p. 110) diz ocorrer quando transformamos determinadas abordagens e estruturas: "Se a análise linguística levar em conta as determinações históricas, por exemplo, ou nos fornecer formas de analisar as operações de poder, a divisão entre os estudos da linguagem e os relatos concretos será rompida". Daí compreendermos que o mundo crítico do texto deva ser lido comparativamente, ou melhor, de modo dialógico, ao texto crítico do mundo (Oliveira, 2010).

Os ininterruptos cruzamentos de fronteiras entre o real e o ficcional configuram um imaginário e devem ser compreendidos por meio desses intercâmbios entre a seleção e a combinação dos elementos que compõem esse novo mundo ressignificado pelo texto literário. A preocupação com os aspectos contextuais concretos suscitados pela leitura não pode, entretanto, ignorar a possibilidade de alargamento do horizonte de expectativas dos leitores, que possuem papel fundamental na reconfiguração desse imaginário. Códigos e convenções sociais não podem ser lidos eficazmente sem que compreendamos a forma como eles serão representados na estrutura textual das obras ficcionais. Fatos de linguagem criam o real, que será apresentado, representado e reapresentado pelo/no texto e, assim, revela-se a importância dos aspectos cognitivos na formulação de ideias e ideologias que constituem determinados contextos.

Na leitura de $O$ filho da mãe, por exemplo, veremos que o enredo central é construído em torno da trajetória de dois jovens, Andrei e Ruslan, e neles se concentra boa parte da focalização heterodiegética do romance. Andrei, filho de uma russa e de um brasileiro, é um recruta convocado pelo exército russo para lutar na Segunda Guerra da Tchetchênia; já Ruslan, filho de mãe russa e pai tchetcheno (saberemos que fora abandonado pela mãe, ainda criança, e cedo se tornará órfão de pai - Chackban, morto em serviço no exército), consegue escapar da guerra, ao cruzar a fronteira da Tchetchênia com a Rússia, auxiliado pela avó, Zainap. Na Rússia se dará o turbulento 
encontro de Andrei e Ruslan, que logo se transforma em uma breve e trágica história de amor. Por meio da história desses jovens, o leitor terá acesso, a nosso ver, a duas possibilidades fundamentais leitura, aparentemente contrapostas: a primeira diz respeito a uma ética da amizade e da hospitalidade representada pela ideia do kunak, em que a vinda e a aceitação do outro é recebida pelo princípio do acolhimento incondicional; a segunda discute a questão da monstruosidade, espécie de híbrido indesejável que atende pelo nome de quimera, entidade portadora de má sorte e caracterizada por um mal a ser extirpado, que na prática dificulta ou barra o processo da hospitalidade.

As imagens do kunak e da quimera são articuladas no texto de Carvalho por meio de estratégias ficcionais que apontam, dialogicamente, para o mundo representado e identificado por meio dos diversos discursos estilizados no romance. Na tradição popular tchetchena, o kunak representa alguém que cada um de nós encontrará ao longo da vida, seja para nos salvar ou para que o salvemos de um perigo, estabelecendo-se de parte a parte vínculos eternos de amizade. Já a quimera é descrita como um híbrido, um indesejável ser monstruoso que, por conta de sua deformidade e estranheza, devemos sacrificar, visando restaurar a ordem social. No caso do romance de Carvalho, esse mundo configura-se como uma espécie de espaço singular de representação do outro, conforme pensou Bakhtin, quando afirmou que os sujeitos ou vozes que falam no romance representam variadas classes sociais, e são expressões autênticas de uma configuração ideológica de mundo (Bakhtin, 1988). Em todo discurso, a posição de cada elemento na cadeia dos significantes determina suas relações com o todo significativo e a cada vez que se deslocam esses elementos, o percurso do significado será igualmente alterado.

A economia textual se articula por meio desse esquema cooperativo entre cadeias de significantes e construções de significados. Todo texto pode ser traduzido pelo que articula em relação ao mundo da vida nele representado: essa "atração pelo mundo" - e podemos entender "mundo" como um contexto determinado, preditivo, um campo composto de correspondências intra e extraliterárias percebidas na relação entre os signos, o que faz com que a descrição e o inventário se revelem ao leitor, que é o agente central desse processo de reconfiguração do imaginário criado. Ao reconhecer que nada pode existir fora do texto, o leitor percebe, entretanto, que uma exterioridade ali se manifesta, de forma suplementar. Como exemplo, digamos que, se o kunak representa no 
romance uma forma alegórica instituída pela estrutura ficcional, remetendo-nos à representação das possibilidades éticas em um ambiente de degradação das formas de convívio, será pelo acréscimo e superposição de elementos e detalhes no texto que os efeitos dessa ação criadora estimularão o pensamento crítico a problematizar o discurso, com o auxílio de múltiplas áreas cooperativas.

Em relação à questão da ética, veremos que ela é historicamente pensada como paradigma do convívio e do bem-estar comum, que elogia e diz privilegiar a alteridade, a diferença e a mobilidade. No entanto, conforme avançam os processos de clausura ficcionalizados no romance, a vigilância, o controle e a violência violam a promessa de mobilidade inscrita nos estatutos da modernidade. Carvalho ficcionaliza essa estrutura fechada por meio de uma narrativa que se articula nos domínios do realismo político. A essa estrutura, que pressupõe a emergência de uma ética, seja de um grupo ou de um sujeito em particular, pode ser depreendida no tema do kunak e inferida na leitura do romance. A essa atitude ética antepõe-se outra, depreendida do pensamento da quimera, elemento de desordem e símbolo da monstruosidade, ou seja, aquilo que deve ser eliminado, posto que desestabiliza o mundo organizado. A figura da quimera expressa o incômodo da deformidade, constituída por um defeito, uma anomalia expressa no abjeto que perturba a linearidade do progresso e os preceitos da razão instrumental.

Não por acaso, $O$ filho da mãe ficcionaliza e repensa a noção de barbarós, do estrangeiro, do desconhecido que se apresenta como um corpo estranho à sociedade, causando temor e provocando a xenofobia e demais fobias em face do outro, como no caso de Ruslan, excluído, ao mesmo tempo, de sua pátria tchetchena e da ascendência russa por parte da mãe. Desse modo, $O$ filho da mãe também poderá ser lido como uma ficção que trata da questão do estrangeiro em um mundo que, ou se furta à hospitalidade, como nos estados autoritários, ou a trata sob a tutela de uma condicionalidade. Melhor dizendo, em relação ao caráter incondicional da hospitalidade, o romance aborda o problema do outro como alguém que só pode exercer sua plenitude sob certas "condições". Quanto a isso, podemos identificar algumas estratégias do narrador heterodiegético do romance, em que se observa uma série de imagens que associam o sexo e o amor às guerras e que podem ser uma das chaves de leitura do texto: 
É possível que não se dê conta de que terminou por associar o sexo às ruínas e ao risco, à força de tê-lo descoberto em meio a uma guerra, e de buscá-las, as ruínas, sempre que encontra alguém, por ter sido obrigado a reconhecer nelas o cenário reconfortante do lar onde já não há possibilidade de reconforto (Carvalho, 2009, p. 139).

Já no caso de Andrei, a focalização heterodiegética informa ao leitor que a "euforia silenciosa da personagem provém da descoberta e da estranheza, da novidade de intuir que ali, de alguma forma, em meio ao que resta do mundo perdido à sua volta, compartilha a memória afetiva do homem a seu lado" (Carvalho, 2009, p. 139). Avulta nessa passagem a questão da ruína, que pode ser lida como um detalhe da narrativa, um acréscimo aparentemente acessório, entretanto, pela repetição com que se recorda a todo instante na trama o motivo da ruína, chama atenção do leitor para essas possíveis aberturas interpretativas provocadas pela contínua repetição.

O mundo da guerra terá como correlato o mundo da ruína de Andrei e Ruslan. É um mundo assombrado e de pesadelo no qual os dois jovens protagonistas partilham a experiência crua do sexo na irrealidade do cotidiano opressor, seja pela forma com que tentam sobreviver - Ruslan, ora na sombria São Petersburgo, de prédios arruinados e em situações de perigo, ora na Grózni em guerra; e Andrei, aturdido na São Petersburgo das trezentas pontes que dão em lugar algum e na iminência de ser enviado ao campo de guerra. Para ambos, seja na São Petersburgo em reconstrução ou na arruinada Grózni, resta perambular pelos espaços de exceção das duas cidades, como os prédios desolados onde "os dois só podem existir no limite da inverossimilhança" (Carvalho, 2009, p. 133).

Depuradas da análise textual e conduzidas ao aspecto mais geral da estrutura romanesca de Carvalho, kunak e quimera são mecanismos textuais complementares à crítica política pouco a pouco delineada no romance. É nossa hipótese de trabalho que os signos do kunak e da quimera, ao se endereçarem de forma alegórica para o domínio de um realismo político predominante no romance, vão se descolando do plano mais imediato da trama em si - o encontro entre os dois jovens e futuros amantes -, para se estenderem a uma visão do mundo globalizado em que são expostas as contradições de uma modernidade encurralada entre a mobilidade prometida e a clausura das práticas políticas, sociais e culturais hegemônicas. Nesse sentido, o romance 
pode ser considerado tanto uma história de amor entre dois jovens quanto uma representação alegórica dos limites e das possibilidades de uma nova ética planetária frente a uma modernização que oscila entre um deus da promessa e um outro, que recusa as diferenças em prol de uma ordenação hegemônica do mundo. Quanto a isso, Milton Santos (2002) identificou três formas de globalização: a de fábula, a da perversidade e a possível. Como fábula, a globalização quer-se fazer crer promotora de mobilidade e união na aldeia global em constante deslocamento e transposição de fronteiras, capaz de "homogeneizar o planeta quando, na verdade, as diferenças locais são aprofundadas" (Santos, 2002, p. 19). Como perversidade, percebe-se nos processos de generalização da pobreza, do desabrigo, da fome em escala mundial e da emergência de novos fundamentalismos, uma "perversidade sistêmica que está na raiz dessa evolução negativa da humanidade", problemas cuja raiz está plantada no "presente processo de globalização" (Santos, 2002, p. 20). E como projeto utópico, podemos compreender o mundo como palco para uma "outra globalização", a possível, que pode se valer tanto do momento privilegiado da "mistura de povos, raças, culturas, gostos, em todos os continentes" (Santos, 2002, p. 20) quanto da concentração cada vez maior de pessoas em lugares cada vez menores, permitindo maior integração e trocas, promovendo o que Santos chama de "novo grande relato", no qual, "em um mundo datado como o nosso, a explicação do acontecer pode ser feita a partir de categorias de uma história concreta. É isso também que permite conhecer as possibilidades existentes e escrever uma nova história" (Santos, 2002, p. 21).

As figuras do kunak e da quimera estruturam intensa problematização de temas relevantes como os da nação, nacionalidade, identidade e subjetividade. Por meio deles, vislumbramos, na proposta de Lucia Helena (2009, p. 114), "uma re-configuração" pela qual "a ruína revela-se o índice de um tipo de presença"; "manifesta-se como a presença, em fragmento, do que, embora passado e em desintegração, não desapareceu inteiramente". Helena pensa a leitura literária por meio de "movimentos de passagem" que provocam formas dialógicas que demandam campos teóricos cooperativos. Helena $(2009$, p. 120) destaca em vários romancistas contemporâneos um ponto em comum: "todos os personagens principais se inserem como figurações de um deslocamento". Aproveitando suas considerações a respeito desse circuito discursivo e estendendo-o à 
compreensão do romance $O$ filho da mãe, vemos que os termos identidade e nacionalidade são elementos privilegiados e correlatos ao processo contraditório de constituição da modernidade, que opõe a mobilidade e o progresso à clausura e o retrocesso.

As personagens Andrei e Ruslan se movimentam nos espaços geográficos de um mundo de clausura que é ao mesmo tempo apresentado como espaço de mobilidade. Eles encenam ficcionalmente uma viagem empreendida em uma São Petersburgo que se mostra como espaço alegórico da condição problemática dos sujeitos que por ela circulam:

A cidade foi construída segundo a lógica da visibilidade total. Onde estão, diferentemente do que ocorre nos becos ao longo da linha do trem, e nos prédios com seus labirintos internos perto da praça Vostânia, só há palácios com fachadas intransponíveis e salões dourados, a maioria decrépita, onde no passado nobres e ricos se protegiam da visibilidade das ruas atrás de paredes de espelhos. As avenidas são chamadas de perspectivas. Foram abertas para dar vazão aos desfiles militares e às demonstrações de poder. Não importa se é o czar, o Estado soviético ou a polícia russa quem comanda a marcha. Não há onde se esconder nem para onde fugir. A cidade foi construída para ninguém escapar (Carvalho, 2009, p. 132).

Em São Petersburgo, na "cidade onde tudo se vê", as ruas funcionam como imensos observatórios propiciados por sua arquitetura de visibilidade total. A possibilidade da vigilância continuada denota o estado de tensão em que vivem os dois rapazes, a circular por espaços públicos ameaçadores para os dois "foras da lei": Ruslan, pela condição de homossexual e pela nacionalidade tchetchena, o que se grava por conta de sua condição ilegal na Rússia, para onde rumara na tentativa de conseguir um passaporte para que pudesse imigrar; Andrei, por ter desertado do exército, devido ao dinheiro do quartel que Ruslan lhe roubara. Conforme aponta o narrador, "juntos, eles podem parecer tudo, menos eles mesmos" (Carvalho, 2009, p. 133). Seus lugares de habitação são esconderijos em prédios arruinados onde se protegem da visibilidade e do patrulhamento constante das ruas. Os espaços por onde se movem dão a justa medida do sistema de controle articulado e da vigilância sistemática a que os sujeitos estão expostos.

Em O filho da mãe, Carvalho elabora alegoricamente a atmosfera opressiva e controladora da São Petersburgo ficcionalizada, seja pelas referências a "O capote", de Nikolai Gogol; pela citação do poema "A 
mulher de lábios azuis", de Anna Akhmátova; ou através das referências ao Hadji Murad, de Leo Tolstói e a Pais e filhos, de Ivan Turguêniev. Os paradigmas de controle que a ficção problematiza através da cidade-observatório que tudo vê aliam-se aos modelos literários exemplares que no passado também tematizaram a cidade como um Grande Irmão aterrador. As referências intertextuais - de Nikolai Gogol, Leo Tolstói, Mikhail Lermontov, Ivan Turguêniev, Anna Akhmátova etc. - refundam paradigmas da estética realista do século XIX e da poesia desencantada do início do século XX, com especial foco nos temas e textos da literatura russa. ${ }^{4}$

A mobilidade prometida e não realizada, a clausura dos sujeitos em trânsito e que se aventuram em uma travessia perigosa e fatal dizem muito sobre o naufrágio da ideia de progresso e o romance de Carvalho espelha bem esses cataclismos. Não se trata aqui de generalizar aspectos problemáticos de um tipo de modernidade em crise, mas, sim, de explicitar aquilo que a relação entre ficção e história no romance expressa e manifesta a seu leitor. Não podemos deixar de vê-la como representação de uma visão desencantada do mundo. A movimentação dos sujeitos nos espaços da grande cidade moderna é representada como uma experiência de sobressaltos, só aplacada por uma possibilidade ética, representada, como dissemos, na ideia do kunak: "Segundo as tradições inguches, um estrangeiro, ou membro de outro clã ou de outra tribo, com quem se estabelece um pacto de proteção e fraternidade" (Carvalho, 2009, p. 39). Esse pacto será ficcionalizado por Carvalho através do dialogismo que articula ficção e mundo. A ideia do kunak se mostra potencialmente transgressora em suas possibilidades humanas, éticas, mas não no sentido da transgressão como revolta violenta, dada a impotência

\footnotetext{
${ }^{4}$ Embora não seja nossa proposta neste artigo, é importante lembrar o texto seminal de Roman Jakobson, em A geração que esbanjou seus poetas (2006). Nessa obra, Jakobson biografou e contextualizou criticamente a morte dos poetas russos mais representativos nas primeiras décadas do século XX: Aleksandr Blok (que definha, isolado, até a morte, em 1921); Nikolai Gurmilov (fuzilado, também em 1921); Velimir Khlébnikov (as privações o levaram à morte, em 1922); Sierguéi Iessiênin (suicidou-se, em 1925) e Vladimir Maiakóvski (suicidou-se em 1930), para ficarmos somente nesses nomes mais representativos. Com a década de 1930, acabaram-se os sonhos de uma possibilidade mais humana para o socialismo soviético. Os expurgos e as prisões em massa, os assassinatos cometidos pelo estado e a implantação de uma ditadura sangrenta que teve em Josef Stalin seu símbolo maior levaram Jakobson a escrever um opúsculo em que nos dá ciência dos rumos trágicos do movimento comunista, que ascende a um tipo novo de totalitarismo, descambando para os eventos bem conhecidos na história do século XX e cuja culminância será a Segunda Guerra Mundial.
} 
dos sujeitos transgressores de efetivamente ultrapassarem a ordem que os oprime. O sentido dado à ideia do kunak desafia a ordem quando opõe à truculência da repressão e à violência do poder uma ética da hospitalidade.

A possibilidade de estabelecimento dessa "utopia do precário", como afirmou Lucia Helena, pode ser uma resposta possível para se pensar o aprimoramento das relações humanas em tempos de desconstrução generalizada dos paradigmas, que nos lança em uma visão desencantada do mundo da técnica, do mercado e da mercadoria, algo que também deve ser revisto, repensado, relativizado e problematizado. Contra a ameaça da instituição de um espaço de clausura, uma possibilidade humana se anuncia nos "pequenos gestos" que fazem vibrar o melhor nas qualidades humanas quanto às políticas da diferença e da convivência. É no exercício da hospitalidade que se articula uma "ética mínima", resistente a imperativos e impedimentos. Por isso, ela é necessária, já que nos faz pensar, como se vê nas páginas do romance de Carvalho, uma ideia de amizade conforme expressa nas ações de Andrei ao tentar salvar seu kunak, Ruslan. Não se trata de exemplaridade, nem de escrita de autoajuda, mas de uma imagem construída no texto sob a forma de um engajamento não panfletário.

As personagens Ruslan e Andrei encenam, cada uma a seu modo, as relações de amizade que norteiam as tradições tchetchenas e atendem pelo nome kunak. Para salvar o inesperado amigo que acabara de ser espancado, Andrei abre mão de seu passaporte e o coloca nas roupas de Ruslan na esperança de ajudá-lo a escapar do país. No entanto, Ruslan não resiste aos ferimentos e morre, frustrando a tentativa de Andrei. No entanto, o ato de coragem e desprendimento de seu kunak fica para o leitor como metáfora da condição humana representada na obra. O mundo anunciado nas primeiras páginas da narrativa é, de um lado, marcado por uma estrutura de impedimentos que isola os atos de amor como os de Andrei em relação a Ruslan. Esse mundo é representado na figura de Ruslan, sujeito que personifica os efeitos nocivos da promessa adiada e da utopia barrada, mas que também alegoriza a "globalização possível" pensada por Milton Santos.

Queremos afirmar que não é nosso objetivo ler $O$ filho da mãe sob o prisma de um niilismo deslocado. A investigação no romance revela as formas que estruturam um certo domínio do realismo na prosa de Carvalho e nos auxiliam a ver mais objetivamente a opção do autor por 
uma ficcionalização crítica da história em um mundo em transformação. O discurso literário se revela por meio de passagens em que Iúlias, Zainaps, Marinas, Andreis e Ruslans representam a falência da promessa moderna quanto ao bem-estar comum. Com esses personagens, deparamos a oportunidade de se (re)construir outras trezentas pontes, que liguem o eu ao outro: um eu que deve ir, não de encontro, mas ao encontro do outro na promessa de uma hospitalidade sincera, conforme uma ética da hospitalidade que possa dar conta das novas configurações humanas na paisagem contemporânea. Nesse sentido, a fala de Jacques Derrida (2003, p. 5) é poeticamente reveladora:

A questão do estrangeiro não seria uma questão de estrangeiro? Vinda do estrangeiro? Antes de dizer $a$ questão do estrangeiro, talvez se devesse precisar: questão do estrangeiro. Essa diferença de acento, como entendê-la? Existe, como dizíamos, uma questão do estrangeiro. É urgente abordá-la - como tal.

Para Derrida, antes de se tomá-la como conceito ou tema, a questão do estrangeiro deve ser compreendida como questão oriunda da própria noção de estrangeiro, e deve ser posta por ele e a ele dirigida, ou seja: devemos compreender o estrangeiro, ao mesmo tempo, como aquele que coloca em jogo sua própria questão e espera do outro a quem a questão é dirigida uma abertura para negociações e reformulações que não terminem em capitulação ou rendição. Derrida propõe partirmos do lugar do estrangeiro para que possamos devidamente interrogar esse estrangeiro. Nesse sentido, a relação estabelecida entre eu e outro é sempre a de um determinado posicionamento: como me coloco diante do outro, como o vejo, como o outro me vê e coloca a mim sua questão, para que eu possa problematizar, tanto a mim como a ele?

Recorrendo à história, Derrida nos trará a lembrança de que na Atenas antiga o estrangeiro tinha acesso a tribunais, ou seja, havia direito à hospitalidade jurídica. Entretanto, tratava-se de uma cidadania oferecida a alguém que não a tinha, como um direito concedido ao estrangeiro que permanecia estrangeiro, comprometido com os deveres de sua condição. Além disso, para o grego, o direito à hospitalidade pressupunha "uma casa, uma linhagem, uma família, um grupo familiar ou étnico recebendo um grupo familiar ou étnico" (Derrida, 2003, p. 35). Não se abrigava, portanto, um anônimo, mas alguém identificado e ligado a um determinado grupo. Era preciso que o sujeito tivesse um nome e este nome o ligava a seu grupo 
familiar, clã ou etnia de origem, isto é, ofertava-se, na verdade, uma "hospitalidade condicional" por meio de um pacto de aceitação que pressupunha a representação e a proteção de um nome de família que tornasse exequível a hospitalidade. Para Derrida, aquela lei era deveras paradoxal, já que o acolhimento se dava por conta de uma condição: a política do nome. Hoje, como substitutivo a ela, o filósofo propõe a hospitalidade absoluta, que rompa com a lei da hospitalidade condicional:

Em outros termos, a hospitalidade absoluta exige que eu abra minha casa e não apenas ofereça ao estrangeiro (provido de um nome de família, de um estatuto de família, de um estatuto social de estrangeiro etc.), mas ao outro absoluto, desconhecido, anônimo, que eu lhe ceda lugar, que eu o deixe vir, que o deixe chegar, e ter um lugar no lugar que ofereço a ele, sem exigir dele nem reciprocidade (a entrada num pacto), nem mesmo seu nome. A lei da hospitalidade absoluta manda romper com a hospitalidade de direito, com a lei ou a justiça como direito. A hospitalidade justa rompe com a hospitalidade de direito; não que ela a condene ou se lhe oponha, mas pode, ao contrário, colocá-la e mantê-la num movimento incessante de progresso; mas também lhe é tão estranhamente heterogênea quanto a justiça é heterogênea no direito do qual, no entanto, está tão próxima (na verdade, indissociável) (Derrida, 2002, p. 24-25).

A hospitalidade incondicional se manifesta mais como promessa do que acontecimento. Podemos dar o exemplo atual dos refugiados, com suas tentativas de encontrar abrigo e solidariedade no continente europeu, e esse mais novo drama nos recorda outro, anterior: os conflitos na Tchetchênia, bem representados no romance de Carvalho. Com isso, é possível termos uma pequena ideia da dimensão humana e trágica desses conflitos. A hospitalidade absoluta, exemplo máximo da tentativa desesperada de Andrei para salvar seu kunak (Ruslan), pode ser lida como um gesto performático de alta voltagem ficcional no romance $O$ filho da mãe, quando chama atenção para as possibilidades humanas que devem sobressair, embora estejam em baixa, no mercado comum da vida.

Em uma breve passagem do romance, o narrador heterodiegético de Carvalho faz o papel de observador ausente: "Tudo está relativamente calmo, o que só faz aumentar a visibilidade dos dois. 
Mais do que qualquer outra, esta é uma cidade de risco, construída para permitir maior visibilidade às forças da ordem" (Carvalho, 2009, p. 106). A calmaria da cidade e os aspectos funcionais de sua organização favorecem o controle e a vigilância, diz o narrador. A configuração espacial de São Petersburgo, como já vimos anteriormente, em vez de propiciar a convivência harmônica e a segurança dos sujeitos na geografia da cidade visa, ao contrário, tornar aquele espaço público visível o suficiente para que melhor se exerça a vigilância e a punição. Dessa forma, uma atmosfera de pesadelo e medo paira na cidade

onde os recém-casados vêm posar para os fotógrafos em cima das pontes, os dois só podem existir no limite da inverossimilhança. Seu encontro só não é impossível porque eles de fato existem, são de carne e osso, ao contrário do fantasma do conto de Gogol que Andrei leu na escola (Carvalho, 2009, p. 106).

A homologia entre o fato histórico marcante na trajetória de Ruslan - a guerra em sua Tchetchênia natal - e as formas de opressão representadas pelo corpo vigilante da cidade de São Petersburgo trazem ao personagem a memória da violência psíquica e a da guerra, a que ele esteve exposto em Grózni e que se reproduz na São Petersburgo de mil olhos:

É possível que não se dê conta de que terminou por associar o sexo às ruínas e ao risco, á força de tê-lo descoberto em meio a uma guerra, e de buscá-las, as ruínas, sempre que encontra alguém, por ter sido obrigado a reconhecer nelas o cenário reconfortante do lar onde já não há possibilidade de reconforto. Quando não há mais nada, há ainda o sexo e a guerra. O sexo e a guerra são o que todo homem tem em comum, rico ou pobre, educado ou não. O sexo e a guerra não se adquirem (Carvalho, 2009, p. 139).

Já para Andrei, a possibilidade ética é representada na trama pela ideia do kunak e se aproxima da hospitalidade absoluta de que trata Derrida. Nessa cadeia de níveis de subalternização, Andrei vê Ruslan como o amigo estrangeiro e desconhecido que deve ser acolhido (seu kunak): "A ideia de uma vulnerabilidade maior que a sua lhe desperta o amor" (Carvalho, 2009, p. 139). Na carta deixada por Ruslan a Andrei, que acaba sendo uma mensagem de despedida, lê-se: "As quimeras morrem para que sobreviva o pacto dos que não podem contar nem com Deus nem com os anjos" (Carvalho, 2009, p. 160-161). Ainda que sombria, sob uma certa ótica, podemos ler assertivamente a visão de 
Carvalho, que estabelece o mundo da vida como terreno onde podem brotar as sementes de uma ética fundamental, urgente na nova organização planetária que se quer possível e humana, conforme defende Derrida, para quem devemos dizer sim

ao que chega, antes de toda determinação, antes de toda antecipação, antes de toda identificação, quer se trate ou não de um estrangeiro, de um imigrado, de um convidado ou de um visitante inesperado, quer o que chega seja ou não cidadão de um outro país, um ser humano, animal ou divino, um vivo ou um morto, masculino ou feminino (Derrida, 2003, p. 69, grifo nosso).

A salvação da quimera pelo kunak, a realização do irrealizável no mundo da lei e da razão instrumental se dá no ambiente da transgressão, que se apresenta como forma de sobrevivência, de resistência aos impedimentos. Como diz Derrida (2003, p. 73, grifo nosso),

A lei, no singular absoluto, contradiz as leis no plural, mas cada vez é a lei na lei e cada vez fora da lei na lei. É isso, a coisa tão singular que se chamam as leis da hospitalidade. Estranho plural, gramática plural de dois plurais diferentes ao mesmo tempo. Um desses dois plurais diz as leis da hospitalidade, as leis condicionais etc.

Ainda com Derrida, diante de uma lei que se promove pela força, nas aporias da "injustiça justa", como força de lei, a narrativa de Carvalho contrapõe a necessidade de um "fora da lei na lei", uma possibilidade ética transgressora:

Porque para o ser que ela deve ser, a hospitalidade não pode pagar uma dívida, nem ser exigida por um dever: grátis, ela não "deve" abrir-se ao hóspede nem "conforme o dever", nem mesmo, para usar ainda a distinção kantiana, "por dever". Essa lei incondicional da hospitalidade, se se pode pensar nisso, seria então uma lei sem imperativo, sem ordem e sem dever. Uma lei sem lei, em suma. Porque, se eu pratico a hospitalidade por dever [e não apenas em conformidade com o dever], essa hospitalidade de quitação não é mais uma hospitalidade absoluta, ela não é mais graciosamente oferecida para além da dívida e da economia, oferecida ao outro, uma hospitalidade inventada pela singularidade do que chega, do visitante inopinado (Derrida, 2003, p. 73, grifo nosso).

A tentativa de salvação do outro se reflete na construção ficcional da personagem Andrei: nele, a possibilidade humana, ética e possível de uma hospitalidade incondicional, embora constantemente sob a 
ameaça da lei, materializa-se nas políticas do acolhimento, equiparáveis ao amor. Por meio da representação do amor carnal e espiritual, da philia e da ética da amizade na confirmação das possibilidades humanas que resistem na ideia do kunak, e na compaixão pelas quimeras - compaixão para conosco, muitas vezes e em vários momentos, quimeras -, o romance deixa em aberto as respostas possíveis à pergunta de Derrida sobre uma ética planetária baseada na hospitalidade incondicional. Quanto a isso, Derrida (2003, p. 133) recorre à fabulação bíblica e relembra a história de Ló, no "momento em que Ló parece colocar as leis da hospitalidade acima de tudo". Ao hospedar dois estrangeiros, Ló incorpora as leis da hospitalidade absoluta, incondicional: "Para proteger a qualquer preço seus hóspedes, sendo chefe de família e pai todo-poderoso, ele oferece aos homens de Sodoma suas duas filhas virgens. Elas ainda não foram 'penetradas' por homens" (Derrida, 2003, p. 134, grifo nosso). Com isso, Ló consegue salvar os estrangeiros, ao custo do sacrifício de suas filhas. Andrei tenta o mesmo, oferecendo-se, sem sucesso, em holocausto. A pergunta que o romance faz é, portanto: vivemos, então, como no passado, em um mundo no qual somente pelo sacrifício, nosso e do outro, poderemos conviver e compartilhar?

O tema da monstruosidade já se manifestava, como vimos no começo deste trabalho, em Grande sertão: veredas, de Guimarães Rosa, e em Lavoura arcaica, de Raduan Nassar. Em contraposição à possibilidade humana de uma ética planetária, Bernardo Carvalho nos coloca diante de um mundo sob a iminência do risco de apagamento do outro (e de nós mesmos, por extensão). E já que "eu é um outro", como na frase de Rimbaud, isso requer de nós, e de forma urgente, repensar as formas comuns de convivência.

A literatura contribui para o campo intelectual como uma fala que soma, não mais ou menos autorizada do que outras, mas talvez melhor aparelhada, por conta de sua força de plurissignificação e de seu poder de trapaça salutar, a promover discursos que nos propiciem pensar a hospitalidade incondicional e uma ética da amizade como paradigmas reflexivos de nosso tempo, que nos ajudem a buscar novas formas convivência e aprendizagem. 


\section{Referências}

BAKHTIN, Mikhail (1988). Questões de literatura e de estética: a teoria do romance. São Paulo: Hucitec. p. 134-163.

BAKHTIN, Mikhail (2014). The dialogic imagination. Edited by Michael Holquist. Translated by Caryl Emerson and Michael Holquist. 19. ed. Austin: University of Texas Press.

CARVALHO, Bernardo (2009). O filho da mãe. São Paulo: Companhia das Letras.

DERRIDA, Jacques (2003). Anne Dufourmantelle convida Jacques Derrida a falar da hospitalidade. São Paulo: Escuta.

HELENA, Lucia (2009). A literatura como passagem: reflexões em torno das ficções em desassossego. Alea, Rio de Janeiro, v. 11, n. 1, p. 111-129, jan./jun.

HELENA, Lucia (2012). Náufragos da esperança: a literatura na era das incertezas. Rio de Janeiro: Oficina Raquel.

HOLQUIST, Michael (2014). Introduction. In: BAKHTIN, Mikhail. The dialogic imagination. Edited by Michael Holquist. Translated by Caryl Emerson and Michael Holquist. 19. ed. Austin: University of Texas Press.

JAKOBSON, Roman (2006). A geração que esbanjou seus poetas. São Paulo: Cosac Naify.

JOHNSON, Richard (2004). O que é, afinal, estudos culturais? In: SILVA, Tomaz Tadeu da (Org.). O que é, afinal, estudos culturais? 3. ed. Belo Horizonte: Autêntica. p. 7-131.

NASSAR, Raduan (1989). Lavoura arcaica. 3. ed. rev. São Paulo: Companhia das Letras.

OLIVEIRA, Paulo César Silva de (2010). Poética da distensão: entre a transcrição da paisagem e a escritura do caminho. Manaus: Muiraquitã.

RIMBAUD, Arthur (1871). Canto de guerra parisiense. Carta a Paul Démeny. Charleville, 15 maio. Tradução de Leo Gonçalves. Disponível em: <https://goo.gl/8CGr4A>. Acesso em: 12 out. 2013.

ROSA, João Guimarães (2006). Grande sertão: veredas. Rio de Janeiro: Nova Fronteira.

SANTOS, Milton (2002). Por uma outra globalização: do pensamento único à consciência universal. 9. ed. Rio de Janeiro; São Paulo: Record.

TOLSTÓI, Leo (2009). Hadji Murad. Mineola, New York: Dover Publications.

Recebido em 7 de novembro de 2016.

Aprovado em 30 de maio de 2017. 


\title{
resumo/abstract/resumen
}

\section{Ética e hospitalidade: o motivo do monstro em $O$ filho da mãe, de Bernardo Carvalho}

\author{
Paulo César S. Oliveira
}

Este artigo parte de uma série histórica na literatura brasileira em que o motivo do monstro é ficcionalizado para destacar as relações entre ficção e história, ética e hospitalidade na leitura do romance $O$ filho da mãe, de Bernardo Carvalho. O mundo social estruturado na obra, conforme a noção de dialogismo, de Mikhail Bakhtin (1988), encontra no conceito de hospitalidade, pensado por Jacques Derrida (2003), uma chave de leitura produtiva para a análise das alegorias do kunak e da quimera, elementos-chave da narrativa. A noção de literatura como passagem, de Lucia Helena (2009), complementa a proposta de análise do mundo social representado por Carvalho.

Palavras-chave: ficção, história, identidade, ética.

\section{Ethics and hospitality: the motive of the monster in $O$ filho da mãe, by Bernardo Carvalho}

Paulo César S. Oliveira

This article takes its point of departure a historical series in Brazilian literature in which monstrosity is a central theme, in order to understand the importance of this motif in contemporary fiction, especially in the interrelated fields of fiction and history, ethics and hospitality, as represented in $O$ filho da mãe, by Bernardo Carvalho. Using Mikhail Bakhtin's (1988) theory of the dialogic imagination and Jacques Derrida's (2003) theories of hospitality, the essay discusses the novel's social world, as well as other narrative elements, such as the figures of kunak and the chimera. The analysis of the novel's social world is complemented by the conceptualization of literature as a passage, proposed by Lucia Helena (2009).

Keywords: fiction, history, identity, ethics.

\section{Ética y hospitalidad: el motivo del monstro en $O$ filho da mãe, de Bernardo Carvalho}

\section{Paulo César S. Oliveira}

Este artículo parte de una serie histórica en la literatura brasileña en la que el motivo del monstruo es ficcionalizado para destacar las relaciones entre ficción e historia, ética y hospitalidad en la lectura de la novela de $O$ filho da mãe, de 
Bernardo Carvalho. El mundo social estructurado en la obra, según el concepto de dialogismo, de Mikhail Bakhtin (1988), encuentra en el concepto de hospitalidad, acuñado por Jacques Derrida (2003), una clave de lectura productiva para el análisis de las alegorías del kunak y de la quimera, elementos clave de la narrativa. La noción de literatura como pasaje, tomada de Lucia Helena (2009), complementa la propuesta de análisis del mundo social representado por Carvalho.

Palabras clave: ficción, historia, identidad, ética. 